\title{
PRAWNE ASPEKTY PROWADZENIA DROGOWEGO TRANSPORTU ODPADÓW
}

\section{LEGAL ASPECTS OF ROAD TRANSPORTATION OF WASTE}

\section{STRESZCZENIE}

Z dniem 23 stycznia 2013 roku weszły w życie przepisy ustawy z dnia 14 grudnia 2012 r. o odpadach ${ }^{1}$ (dalej u.o.), które wprowadziły szereg nowych uregulowań dotyczących gospodarki odpadami, w tym również w zakresie reglamentacji działalności związanej z transportem odpadów. W artykule porównano i oceniono dotychczas obowiązujące i aktualnie przyjęte rozwiązania w zakresie transportu drogowego odpadów. Wskazano wymagania prawne określone w odrębnych

* Magister prawa, doktorantka w Instytucie Nauk Prawnych Polskiej Akademii Nauk.

1 Ustawa z dnia 14 grudnia 2012 r. o odpadach, Dz.U. z 2013 r., poz. 21 ze zm. 
przepisach i określono zakres ich stosowania w przypadku drogowego transportu odpadów. Przeanalizowano również problemy pojawiające się w obszarze stosowania wskazanych przepisów.

\section{Słowa kluczowe}

Odpady; transport odpadów; transport drogowy; gospodarka odpadami.

\section{ABSTRACT}

As of 23 January 2013 the provisions of the new Act on Waste of 14 December 2012 were implemented. The Act introduced a number of new regulations on waste management, including a regulation concerning the transportation of waste. The article compares and assesses former and current solutions in the field of transportation of waste. It indicates legal requirements in separate regulations and it defines the scope of their application in the case of road transportation of waste as well. The most interesting problems connected with the application of presented regulations were also analysed.

\section{Keywords}

Waste; transportation of waste; road transport; waste management.

\section{WPROWADZENIE}

Pojęcie transportu odpadów nie zostało zdefiniowane w ustawie o odpadach i jak podkreśla W. Radecki ${ }^{2}$, nie ma konieczności, aby legalną definicję transportu odpadów wprowadzać. Należy bowiem zaznaczyć, że transport odpadów, podobnie jak transport innych materiałów, jest rodzajem usługi, w przypadku której zastosowanie znajdą przepisy usta-

2 W. Radecki, Ustawa o odpadach. Komentarz, Wolters Kluwer 2013, wydanie elektroniczne. 
wy z dnia 23 kwietnia 1964 r. Kodeks cywilny ${ }^{3}$ (dalej k.c.), ustawy z dnia 15 listopada 1984 r. Prawo przewozowe ${ }^{4}$ (dalej u.p.p.) oraz w przypadku przewozu drogowego, również wymagania określone w przepisach ustawy z dnia 6 września 2001 r. o transporcie drogowym ${ }^{5}$ (dalej u.t.d.). Jak wskazuje K. Karpus ${ }^{6}$, transport odpadów, podobnie zresztą jak transport innych materiałów, to czynność polegająca na przemieszczaniu rzeczy między określonymi miejscami. Legalną definicję transportu odpadów wprowadza natomiast w art. 2 pkt 33 rozporządzenie (WE) nr 1013/2006 Parlamentu Europejskiego i Rady z dnia 14 czerwca 2006 r. ${ }^{7}$, zgodnie z którym transport, „oznacza przewóz odpadów zarówno w transporcie drogowym, kolejowym, powietrznym, jak również morskim lub wodnym śródlądowym". Definicja ta jednoznacznie wskazuje zatem, że rozporządzenie obejmuje w zakresie swej regulacji nie tylko transport drogowy, lecz przemieszczanie odpadów w każdej formie, przy czym, na co zwraca uwagę J. Jerzmański $^{8}$, przemieszczanie, o którym mowa w przywołanym rozporządzeniu, może być „postrzegane zarówno w kontekście krajowym, jak i międzynarodowym".

\section{TRANSPORT ODPADÓW JAKO SZCZEGÓLNA FORMA TRANSPORTU DROGOWEGO}

Polski ustawodawca, w art. 24 ust. 2 u.o. wskazał, że transport odpadów niebezpiecznych powinien być realizowany z zachowaniem przepisów obowiązujących przy transporcie

3 Dz.U. nr 16, poz. 93 ze zm.

4 Tekst jedn.: Dz.U. z 2012 r. poz. 1173 ze zm.

5 Tekst jedn.: Dz.U. z 2012r, poz. 1265 ze zm.

6 K. Karpus, [w:] Ustawa o odpadach. Komentarz, B. Rakoczy (red.), LexisNexis 2013, s. 85.

7 Dz.Urz. UE L 190/1 z 12.07.2006 ze zm.

8 J. Jerzmański, Przemieszczanie odpadów - problemy na styku regulacji, [w:] Wybrane problemy prawa ochrony środowiska, B. Rakoczy, M. Pchałek (red.), Wolters Kluwer 2010, s. 235. 
towarów niebezpiecznych, a zatem ustawy z dnia 19 sierpnia 2011 r. o przewozie towarów niebezpiecznych ${ }^{9}$ (dalej u.p.t.n.), określającej zasady prowadzenia działalności w zakresie krajowego i międzynarodowego przewozu drogowego, koleją i żeglugą śródlądową towarów niebezpiecznych oraz organy i jednostki realizujące zadania związane $\mathrm{z}$ tym przewozem. W myśl art. 4 u.p.t.n. w sprawach nieuregulowanych ustawą, do przewozu towarów niebezpiecznych, w tym do środków transportu i urządzeń transportowych w przypadku transportu drogowego, zastosowanie znajdą wymagania $\mathrm{ADR}^{10}$. Transport drogowy odpadów zasługuje na szczególną uwagę, tą bowiem drogą co do zasady przemieszczane są w Polsce odpady pomiędzy kolejnymi posiadaczami, jak również odbierane od właścicieli nieruchomości odpady komunalne.

Przepisy art. 3 u.t.d. wyznaczają przedmiotowy i podmiotowy zakres ustawy, przy czym art. 3 ust. 1 stanowi numerus clausus wyłączeń spod zakresu przedmiotowego ustawy. Zgodnie $\mathrm{z}$ treścią przywołanego $\mathrm{w}$ art. 3 ust. 1 wyliczenia, przepisy ustawy nie będą miały zastosowania do przewozu drogowego, wykonywanego pojazdami samochodowymi lub zespołami pojazdów przeznaczonymi konstrukcyjnie do przewozu nie więcej niż 9 osób łącznie z kierowcą - w niezarobkowym przewozie drogowym osób, o dopuszczalnej masie całkowitej nieprzekraczającej 3,5 tony w transporcie drogowym rzeczy oraz niezarobkowym przewozie drogowym rzeczy, jak również zespołów ratownictwa medycznego oraz $\mathrm{w}$ ramach usług transportu sanitarnego. $Z$ powyższego wywieść należy, że drogowy transport odpadów wykonywany pojazdami samochodowymi lub zespołami pojazdów o dopuszczalnej masie całkowitej powyżej 3,5 tony w transporcie drogowym rzeczy oraz niezarobkowym przewozie drogowym rzeczy, będzie podlegał przepisom u.t.d.

9 Dz.U. nr 227, poz. 1367 ze zm.

10 Zgodnie z art. 2 pkt 1 ustawy z dnia 19 sierpnia 2011 r. o przewozie towarów niebezpiecznych ADR oznacza Umowę europejską dotyczącą międzynarodowego przewozu drogowego towarów niebezpiecznych (ADR), sporządzoną w Genewie dnia 30 września 1957 r. (Dz.U. z 2011 r. Nr 110, poz. 641), wraz ze zmianami obowiązującymi od dnia ich wejścia w życie w stosunku do Rzeczypospolitej Polskiej. 
Przywołany art. 3 u.t.d., w ust. 2 zawiera katalog przewozów drogowych, które jak podkreśla R. Strachowska ${ }^{11}$, wprawdzie nie są wyłączone spod zakresu przedmiotowego ustawy, natomiast należy do nich stosować odpowiednio przepisy ustawy dotyczące niezarobkowego przewozu drogowego. Katalog ten tworzą cztery rodzaje przewozów, wśród których z punktu widzenia tematyki niniejszego artykułu, na uwagę zasługują przewozy drogowe wykonywane w ramach usług polegających na przewozie odpadów komunalnych lub nieczystości ciekłych, wymienione w art. 3 ust. 2 pkt 2 u.t.d.

Zgodnie z art. 5 ust. 1 u.t.d., podmioty podejmujące i wykonujące transport drogowy, co do zasady obowiązane są do uzyskania zezwolenia na wykonywanie zawodu przewoźnika drogowego, na zasadach określonych w rozporządzeniu Parlamentu Europejskiego i Rady (WE) nr 1071/2009 z dnia 21 października 2009 r. ${ }^{12}$ (dalej rozporządzenie (WE) nr 1071/2009).

Powyższe regulacje wprowadzają zatem pewne dodatkowe wymagania dla prowadzenia działalności w zakresie transportu drogowego w tym również transportu drogowego odpadów. W przypadku bowiem przedsiębiorcy prowadzącego działalność gospodarczą w takim właśnie zakresie, poza koniecznością dokonania wpisu w Centralnej Ewidencji i Informacji o Działalności Gospodarczej lub wpisu do rejestru przedsiębiorców w Krajowym Rejestrze Sądowym, o których mowa w art. 14 ustawy z dnia 2 lipca 2004 r. o swobodzie działalności gospodarczej ${ }^{13}$ (dalej u.s.d.g.), pojawia się konieczność spełnienia dodatkowego wymagania w postaci uzyskania zezwolenia na wykonywanie zawodu przewoźnika drogowego. Takie zezwolenie jest udzielane przedsiębiorcy, jeżeli spełnia wymagania określone w rozporządzeniu (WE) nr 1071/2009, a w stosunku do zatrudnionych przez przedsiębiorcę kierowców, a także innych osób

11 R. Strachowska, Ustawa o transporcie drogowym. Komentarz, Wolters Kluwer 2012, wydanie elektroniczne.

12 Rozporządzenie Parlamentu Europejskiego i Rady (WE) nr 1071/2009 z dnia 21 października 2009 r. ustanawiające wspólne zasady dotyczące warunków wykonywania zawodu przewoźnika drogowego i uchylające dyrektywę Rady 96/26/WE, Dz.Urz. UE L 300/51 z 14.11.2009 ze zm.

13 Tekst jedn.: Dz.U. z 2013 r., poz. 672 ze zm. 
niezatrudnionych przez przedsiębiorcę, lecz wykonujących osobiście przewóz na jego rzecz - nie orzeczono zakazu wykonywania zawodu kierowcy.

Jak wskazano powyżej, w przypadku przewozów drogowych wykonywanych w ramach usług polegających na przewozie odpadów komunalnych lub nieczystości ciekłych, wymienionych w art. 3 ust. 2 pkt 2 u.t.d., zastosowanie znajdą przepisy u.t.d., dotyczące niezarobkowego przewozu drogowego, zdefiniowanego w art. 4 pkt 4 u.t.d. i określanego w treści u.t.d. również jako przewóz na potrzeby własne. Tego rodzaju przewozy, jak wyraźnie stanowi art. 33 ust. 1 w związku z ust. 2 u.t.d., mogą być wykonywane po uzyskaniu stosownego zaświadczenia.

\section{REGULACJE W ZAKRESIE TRANSPORTU ODPADÓW NIEBEZPIECZNYCH}

Z brzmienia art. 24 ust. 2 u.o. wynika, że szczególnym wymaganiom podlega transport odpadów niebezpiecznych, a zatem $\mathrm{w}$ rozumieniu art. 3 ust. 4 u.o., odpadów wykazujących co najmniej jedną spośród właściwości niebezpiecznych, które określa załącznik nr 3 do u.o. Transport tego rodzaju odpadów, powinien być realizowany z zachowaniem przepisów obowiązujących przy transporcie towarów niebezpiecznych, przy czym jak już wcześniej sygnalizowano, kluczowe znaczenie będą miały przepisy u.p.t.n. i ADR, które określają obowiązki uczestników przewozu drogowego towarów niebezpiecznych, definiowanych $\mathrm{w}$ art. 2 pkt 8 u.p.t.n. jako podmioty wymienione w ADR lub jednostki wojskowe, prowadzące działalność związaną z przewozem towarów niebezpiecznych.

W myśl art. 14 ust. 1 u.p.t.n., uczestnik przewozu towarów niebezpiecznych, a zatem również podmiot prowadzący działalność związaną z przewozem odpadów niebezpiecznych klasyfikowanych jako towary niebezpieczne ADR, jest obowiązany przeszkolić osoby wykonujące czynności związane z przewozem drogowym, towarów niebezpiecznych, zatrudnione 
przez niego lub wykonujące na jego rzecz czynności związane z przewozem towarów niebezpiecznych przed podjęciem tych czynności, w zakresie odpowiednim do odpowiedzialności i obowiązków tych osób. Szkolenie powinno być okresowo uzupełnianie $\mathrm{w}$ celu uwzględnienia zmian $\mathrm{w}$ przepisach dotyczących przewozu towarów niebezpiecznych. Warto zaznaczyć, że co do zasady uczestnik przewozu towarów niebezpiecznych jest zgodnie z art. 15 ust. 1 u.p.t.n., obowiązany wyznaczyć na swój koszt co najmniej jednego doradcę do spraw bezpieczeństwa przewozu towarów niebezpiecznych, właściwego ze względu na zakres wykonywanego przewozu lub czynności z nim związanych. Ponadto z punktu widzenia przedsiębiorcy prowadzącego działalność w zakresie transportu drogowego odpadów niebezpiecznych, klasyfikowanych jako towary niebezpieczne ADR, istotne znaczenie będą miały wymagania przewidziane dla kierujących pojazdami przewożącymi towary niebezpieczne, należy bowiem wskazać, że do kierowania pojazdem przewożącym towary niebezpieczne w przewozie drogowym, w stosunku do którego ADR wymaga ukończenia przez jego kierowcę kursu ADR, jest uprawniona osoba, która posiada ważne zaświadczenie ADR. Zaświadczenie takie otrzymuje osoba, która zgodnie z art. 20 ust. 2 u.p.t.n., co do zasady ukończyła 21 lat, spełnia wymagania określone $\mathrm{w}$ przepisach prawa o ruchu drogowym i o transporcie drogowym w stosunku do kierowców wykonujących przewóz drogowy, ukończyła odpowiedni kurs ADR i złożyła z wynikiem pozytywnym egzamin kończący ten kurs. Mając na względzie powyższe należy zatem stwierdzić, że w przypadku przedsiębiorcy prowadzącego działalność gospodarczą w zakresie transportu odpadów niebezpiecznych, klasyfikowanych jako towary niebezpieczne ADR, poza przywołanymi już uprzednio wymaganiami, zastosowanie znajdą również szczególne wymagania związane z kompetencjami osób wykonujących określone czynności w ramach tego rodzaju działalności.

Jak zwrócił uwagę M. Górski ${ }^{14}$, przepisy regulujące obowiązek uzyskania zezwolenia na transport odpadów, w żaden

14 M. Górski, Zbieranie i transport odpadów, „Przegląd Komunalny” 2008, nr 2, s. 32 . 
sposób nie wyłączają, jak również nie zastępują przepisów dotyczących zasad prowadzenia transportu materiałów w ogóle. Jednocześnie należy skonstatować, iż posiadanie zezwolenia na wykonywanie zawodu przewoźnika drogowego, a także ukończenia przez jego kierowców kursu ADR i wyznaczenie doradcy do spraw bezpieczeństwa przewozu, nie uprawniają jeszcze do transportu odpadów, w tym w szczególności odpadów niebezpiecznych.

\section{FORMY REGLAMENTACJI PROWADZENIA DROGOWEGO TRANSPORTU ODPADÓW}

Obowiązujący przed dniem 23 stycznia 2013 roku, art. 28 ust. 1 ustawy o odpadach z 2001 r. (dalej u.o. z 2001 r. $^{15}$ ), ustanawiał zasadę, zgodnie z którą transport odpadów wymagał uzyskania zezwolenia. Wyjątki od tej generalnej reguły, określone zostały w art. 31 ust. 1, art. 32 ust. 1 oraz art. 33 ust. 1a i 4 wskazanej ustawy. Ponadto na podstawie jej art. 28 ust. 9, z obowiązku uzyskania zezwolenia na transport odpadów, zwolnieni zostali wytwórcy, którzy transportowali wytworzone przez siebie odpady.

Zgodnie z art. 33 ust. 1a u.o. z 2001 r., transport określonych rodzajów odpadów przez osoby fizyczne i jednostki organizacyjne niebędące przedsiębiorcami do miejsca wykorzystania tych odpadów, w ogóle nie wymagał zezwolenia na transport odpadów.

Nieco inny charakter ma natomiast zwolnienie $\mathrm{z}$ obowiązku uzyskania zezwolenia na transport odpadów, określone w wydanym na podstawie art. 33 ust. 4 u.o. z 2001 r. rozporządzeniu Ministra Gospodarki, Pracy i Polityki Społecznej z dnia 23 grudnia 2003 r. ${ }^{16}$, które w zakresie transportu odpadów,

15 Ustawa z dnia 27 kwietnia 2001 r. o odpadach, tekst jedn.: Dz.U. z 2010 r. Nr 185, poz. 1243 ze zm.

16 Rozporządzeniu Ministra Gospodarki, Pracy i Polityki Społecznej z dnia 23 grudnia 2003 r. w sprawie rodzajów odpadów, których zbieranie lub trans- 
pozostaje aktualne do czasu utworzenia rejestru na podstawie art. 49 ust. 1 u.o. W załączniku do rozporządzenia określone zostały rodzaje odpadów, których transport nie wymaga zezwolenia na prowadzenie działalności w zakresie transportu odpadów, natomiast w $\S 7$ rozporządzenia sprecyzowano warunki takiego transportu. Warto wskazać, co podkreślił w uzasadnieniu wyroku z 14.12.2006 r., WSA w Warszawie, sygn. VI SA/Wa1795/06 ${ }^{17}$, że przepisy rozporządzenia nie zwalniają z obowiązku uzyskania zezwolenia w przypadku każdego transportu odpadów wymienionych w załączniku do rozporządzenia, a jedynie transportu na „ściśle określonych trasach”, tj. między określonymi w rozporządzeniu podmiotami.

Należy zaznaczyć, że w myśl art. 33 ust. 5 u.o. z 2001 r., prowadzący transport odpadów, który jest zwolniony z obowiązku uzyskiwania zezwolenia na prowadzenie tej działalności zgodnie z przepisami wydanymi na podstawie ust. 4, miał obowiązek zgłoszenia do rejestru prowadzonego przez starostę właściwego ze względu na miejsce siedziby lub zamieszkania prowadzącego transport odpadów.

Obowiązująca do dnia 23 stycznia 2013 roku ustawa o odpadach, przewidywała ponadto praktyczne i znacznie upraszczające proces uzyskiwania zezwoleń rozwiązanie, umożliwiające łączenie decyzji związanych z gospodarowaniem odpadami. Na podstawie art. 31 u.o. z 2001 r., wytwórca odpadów, który prowadził odzysk, unieszkodliwianie, zbieranie lub transport odpadów, na skutek odpowiedniego ukształtowania wniosku o wydanie pozwolenia na wytwarzanie odpadów lub decyzji zatwierdzającej program gospodarki odpadami niebezpiecznymi, mógł uzyskać jedną decyzję uwzględniającą powyższe zagadnienia. Podobną konstrukcję dla posiadaczy odpadów, którzy łącznie prowadzili odzysk lub unieszkodliwianie odpadów oraz zbieranie lub transport, przewidywał art. 32 u.o. z 2001 r. Na skutek odpowiedniego ukształtowania wniosku o wydanie zezwolenia na prowadzenie działalności w zakresie odzysku lub

port nie wymagają zezwolenia na prowadzenie działalności, Dz.U. z 2004 r. Nr 16, poz. 154 ze zm.

17 LEX nr 312049. 
unieszkodliwiania odpadów mogli oni uzyskać jedną decyzję, uwzględniającą również wymagania przewidziane dla zezwolenia na zbieranie lub transport odpadów.

Przepisy ustawy z dnia 14 grudnia 2012 r. o odpadach, kwestię transportu odpadów uregulowały w odmienny sposób. Przede wszystkim, docelowo w ogóle nie będą funkcjonowały zezwolenia na transport odpadów. Oczywiście brak zezwoleń nie oznacza, że ustawodawca całkowicie zrezygnował z reglamentacji działalności związanej z transportem odpadów. Przepisy art. 49 u.o., przewidują utworzenie przez marszałka województwa rejestru podmiotów wprowadzających produkty, produkty w opakowaniach i gospodarujących odpadami. Wśród podmiotów, które będą podlegały wpisowi do rejestru, ustawodawca wymienił w art. 50 ust. 1 pkt 5 lit. b u.o. - transportujących odpady. Co do zasady zatem, zgodnie z art. 50 ust. 2 i ust. 3 u.o., działalność w zakresie transportu odpadów będzie mógł prowadzić wyłącznie podmiot wpisany do rejestru. Co do zasady, gdyż jak to miało miejsce $\mathrm{w}$ stanie prawnym sprzed 23 stycznia 2013 roku, reglamentacji, czyli wpisowi do rejestru zgodnie z art. 51 ust. 2 pkt 1 i 4 u.o., nie będą podlegały osoby fizyczne oraz jednostki organizacyjne niebędące przedsiębiorcami wykorzystujące odpady na potrzeby własne, a także transportujący wytworzone przez siebie odpady.

\section{REGLAMENTACJA PROWADZENIA TRANSPORTU ODPADÓW W USTAWIE Z DNIA 14 GRUDNIA 2012 R. 0 ODPADACH}

Do dnia 9 lipca 2014 roku, rejestry, o których mowa w art. 49 u.o. nie zostały jeszcze utworzone. Zgodnie z art. 234 u.o., mają powstać najpóźniej w terminie 36 miesięcy od dnia wejścia w życie ustawy z dnia 14 grudnia 2012 r. o odpadach, czyli do dnia 23 stycznia 2016 roku. Powstaje zatem pytanie, co stanowi formalną podstawę prowadzenia działalności w zakresie transportu odpadów do czasu ich utworzenia. Ustawodawca przewidział rozwiązanie przejściowe, które jednak wydaje się 
nie jest w pełni spójne. W myśl art. 233 ust. 1 u.o., zezwolenia na transport odpadów wydane na podstawie przepisów dotychczasowych zachowują ważność na czas, na jaki zostały wydane, nie dłużej jednak niż do czasu upływu terminu do złożenia wniosku o wpis do rejestru lub z dniem uzyskania wpisu do tego rejestru, w przypadku gdy wpis nastąpił w terminie wcześniejszym. Ponadto w myśl art. 250 ust. 3 u.o., przepisy wydane na podstawie art. 33 ust. 4 i 11 u.o. z 2001 r., zachowują moc w zakresie transportu odpadów do czasu utworzenia rejestru, o którym mowa w art. 49 ust. 1 u.o. Zgodnie z art. 233 ust. 2 i 3 u.o., do czasu utworzenia rejestru prowadzonego przez marszałka, transportujący odpady są obowiązani do uzyskania zezwolenia na transport odpadów lub wpisu do rejestru, o którym mowa w art. 33 ust. 5 u.o. z 2001 r., a do wydawania zezwoleń na transport odpadów do czasu utworzenia rejestru, stosuje się przepisy ustawy z dnia 27 kwietnia 2001 r. o odpadach.

Uwzględniając treść ust. $3 \mathrm{w}$ art. 235 u.o., zgodnie z którym do czasu utworzenia „nowego” rejestru, do rejestrów stosuje się przepisy dotychczasowe, sytuacja transportujących odpady którzy posiadają zezwolenie na transport odpadów wydane na podstawie przepisów dotychczasowych, jak również transportujących odpady, którzy dokonali wpisu do rejestru prowadzonego na podstawie przepisów dotychczasowych przez starostę wydaje się być klarowna. Wątpliwości pojawiają się w odniesieniu do tych podmiotów, które przed wejściem w życie przepisów ustawy z dnia 14 grudnia 2012 r. o odpadach, działalność związaną z transportem odpadów, uregulowały w jednej z tzw. decyzji łącznych, przewidzianych przez art. 31 lub 32 ustawy z dnia 27 kwietnia 2001 r. o odpadach.

Zgodnie z treścią art. 232 ust. 3 u.o., decyzje wydane na podstawie art. 31 ust. 3 i art. 32 ust. 3 u.o. z 2001 r., zachowują ważność w zakresie zbierania, odzysku lub unieszkodliwiania odpadów na czas, na jaki zostały wydane, nie dłużej niż przez dwa lata od dnia wejścia w życie ustawy. Jak podkreśla K. Karpus ${ }^{18}$,

18 K. Karpus, [w:] Ustawa o odpadach. Komentarz, B. Rakoczy (red.), LexisNexis 2013, s. 133. 
na co zwrócił uwagę również W. Radecki ${ }^{19}$, z brzmienia art. 232 ust. 3 u.o. wywieść należy, iż na podstawie decyzji przywołanych we wskazanym przepisie, posiadacze odpadów mogą nie dłużej niż do 23 stycznia 2015 roku prowadzić zbieranie lub przetwarzania odpadów. Jednocześnie należy wskazać, że w art. 232 ust. 2 u.o. ustawodawca wyraźnie zaznaczył, iż zezwolenia na zbieranie odpadów oraz zezwolenia na odzysk lub unieszkodliwianie odpadów, wydane na podstawie przepisów dotychczasowych, zachowują ważność na czas, na jaki zostały wydane, nie dłużej jednak niż przez dwa lata od dnia wejścia w życie ustawy. Z zestawienia powyższych przepisów można wnioskować, iż decyzje łączne nawet jeśli regulują kwestie zbierania, odzysku lub unieszkodliwiania odpadów, stanowią pewnego rodzaju odrębną kategorię i są czym innym niż zezwolenie na zbieranie, zezwolenie na odzysk lub zezwolenie na unieszkodliwianie odpadów. Należy zatem przyjąć, iż również zezwolenie na transport odpadów jest decyzją innego rodzaju niż ta, o której mowa w art. 31 lub art. 32 u.o. z 2001 r., nawet jeśli uwzględnia ona swym zakresem transport odpadów, co z kolei prowadzi do wniosku, iz decyzje wydane na podstawie art. 31 ust. 3 i art. 32 ust. 3 u.o. z 2001 r., w zakresie transportu odpadów swej ważności nie zachowują. Tym samym należy przyjąć, że podmioty, które prowadzą transport odpadów, a dotychczas działały na podstawie tego rodzaju decyzji, obowiązane są do uzyskania zezwolenia na transport odpadów na podstawie art. 28 u.o. z 2001 r. lub wpisu do rejestru, o którym mowa w art. 33 ust. 5 u.o. z 2001 r. Należy przy tym podkreślić, że w odniesieniu do decyzji łącznych, których wydanie przewidziano również w ustawie $\mathrm{z}$ dnia 14 grudnia 2012 r. o odpadach, ustawodawca uregulował powyższą kwestię, wskazując jednoznacznie w art. 41 ust. 9 u.o., iż tam, gdzie w ustawie jest mowa o zezwoleniu na zbieranie odpadów lub zezwoleniu na przetwarzanie odpadów rozumie się przez to również zezwolenie na zbieranie i przetwarzanie odpadów, a zatem zezwolenie łączne.

19 W. Radecki, Ustawa o odpadach. Komentarz, Wolters Kluwer 2013, wydanie elektroniczne. 


\section{SZCZEGÓLNE WYMAGANIA W ZAKRESIE TRANSPORTU ODPADÓW KOMUNALNYCH}

Odrębne zagadnienie, stanowią wymagania dotyczące transportu odpadów komunalnych, definiowanych $\mathrm{w}$ art. 3 ust. 1 pkt 7 u.o., jako „odpady powstające w gospodarstwach domowych, z wyłączeniem pojazdów wycofanych z eksploatacji, a także odpady niezawierające odpadów niebezpiecznych pochodzące od innych wytwórców odpadów, które ze względu na swój charakter lub skład są podobne do odpadów powstających w gospodarstwach domowych". Wymagania związane $\mathrm{z}$ transportem tego rodzaju odpadów uregulowane zostały przede wszystkim w ustawie z dnia 13 września 1996 r. o utrzymaniu czystości i porządku w gminach ${ }^{20}$ - dalej u.c.i.p.g., chociaż zastosowanie znajdą tu również wymagania przewidziane w zakresie transportu odpadów określone w ustawie o odpadach, jak również innych przywołanych przepisach.

Bezspornie, działalność w zakresie odbierania odpadów komunalnych od właścicieli nieruchomości jest działalnością regulowaną $\mathrm{w}$ rozumieniu u.s.d.g. Powyższe wynika wprost $\mathrm{z}$ art. 9b u.c.i.p.g. Zmiana sposobu reglamentacji tego rodzaju działalności i zastąpienie zezwolenia wpisem do rejestru działalności regulowanej, stanowiło zdaniem W. Radeckiego ${ }^{21}$ jedną z bardziej istotnych zmian jakie wprowadziła ustawa z dnia 1 lipca 2011 r. o zmianie ustawy o utrzymaniu czystości i porządku w gminach oraz niektórych innych ustaw ${ }^{22}$. Przedsiębiorca odbierający odpady komunalne od właścicieli nieruchomości jest zatem obowiązany w myśl art. 9c ust. 1 u.s.d.g. do uzyskania wpisu do rejestru w gminie, na terenie której zamierza odbierać odpady komunalne od właścicieli nieruchomości.

Podkreślić należy, że w doktrynie brak jednoznacznego stanowiska, czy w przypadku transportu odpadów komunal-

20 Tekst jedn.: Dz.U. z 2013 r., poz. 1399 ze zm.

21 W. Radecki, Ustawa o utrzymaniu czystości i porządku w gminach. Komentarz, Wolters Kluwer 2012, wydanie elektroniczne.

22 Dz.U. nr 152, poz. 897. 
nych wymagane jest również uzyskanie zezwolenia na transport odpadów. Wydaje się jednak, że podmiot prowadzący tego rodzaju działalność, niezależnie od dokonania wpisu do rejestru działalności regulowanej, powinien uzyskać również zezwolenie na transport odpadów. Niezależnie od powyższego, po utworzeniu rejestru podmiotów wprowadzających produkty, produkty w opakowaniach i gospodarujących odpadami, podmioty prowadzące działalność regulowaną w zakresie odbierania odpadów komunalnych od właścicieli nieruchomości, zostaną do niego wpisane. O ile nie zostaną wpisani do rejestru na wniosek, zgodnie z art. 51 ust. 1 pkt 6 u.o. w związku $\mathrm{z}$ art. 49 ust. 3 u.o., wpisu z urzędu dokona właściwy ze względu na miejsce zamieszkania lub siedzibę podmiotu - marszałek województwa.

Należy jednak podkreślić, że o ile rejestr przedsiębiorców odbierających odpady komunalne od właścicieli nieruchomości, stanowi rejestr działalności regulowanej w rozumieniu art. 64 ust. 1 u.s.d.g., to już rejestr prowadzony przez marszałka województwa, o którym mowa w art. 49 u.o., takiego charakteru nie ma. Chociaż trzeba zaznaczyć, że wpis do rejestru w przypadku prowadzących transport odpadów, ma charakter reglamentacyjny.

Analizując prawne uwarunkowania związane $\mathrm{z}$ prowadzeniem działalności w zakresie transportu odpadów, nie można pominąć wymagań skierowanych do podmiotów, które działając na zlecenie innego posiadacza odpadów jedynie transportują odpady. Takie podmioty są bowiem zgodnie z art. 24 ust. 3 i 4 u.o., obowiązane dostarczyć odpady do miejsca przeznaczenia oraz posiadacza odpadów, które zostały im wskazane przez zlecającego usługę. Transportujący odpady wykonujący usługę transportu odpadów obowiązani są również do umieszczania indywidualnego numeru rejestrowego na dokumentach związanych z usługą. Jak wskazuje K. Karpus $^{23}$, numer taki powinien zostać umieszczony „przynajmniej w treści umowy", co mogłoby sugerować, że w przypadku

23 K. Karpus, [w:] Ustawa o odpadach. Komentarz, B. Rakoczy (red.), LexisNexis 2013, s. 86. 
zlecenia usługi transportu odpadów, konieczne jest zawarcie umowy w formie pisemnej.

Należy jednak zaznaczyć, że o ile w przypadku niektórych właścicieli nieruchomości, istnieje wynikający z art. 6 ust. 1 pkt 2 u.u.c.i.p.g. obowiązek dokumentowania $\mathrm{w}$ formie umowy faktu korzystania z usług w zakresie odbierania odpadów komunalnych, co jak podkreśla B. Rakoczy ${ }^{24}$, może wręcz prowadzić do wniosku, że „prawodawca akcentuje przede wszystkim kwestie udokumentowania wykonywania obowiązku poprzez okazywanie umowy", to w przypadku zlecania usługi transportu odpadów innych niż komunalne, obowiązku zawarcia umowy $\mathrm{w}$ formie pisemnej nie przewidziano. Zatem umieszczanie numeru $\mathrm{w}$ treści umowy należałoby uznać za warunek sine qua non jedynie wówczas, gdy taka umowa $\mathrm{w}$ formie pisemnej w ogóle zostanie zawarta.

\section{PODSUMOWANIE}

Forma reglamentacji działalności gospodarczej, jak również inne szczególne ograniczenia z nią związane, mają niewątpliwie kluczowe znaczenie dla przedsiębiorców.

Należy zwrócić uwagę na fakt, że poza tym aspektem, również sam sposób prowadzenia działalności polegającej na drogowym transporcie odpadów jest przedmiotem szczególnej regulacji. W myśl art. 24 u.o., transport odpadów powinien odbywać się „zgodnie z wymaganiami w zakresie ochrony środowiska oraz bezpieczeństwa życia i zdrowia ludzi, w szczególności w sposób uwzględniający właściwości chemiczne i fizyczne odpadów, w tym stan skupienia, oraz zagrożenia, które mogą powodować odpady". Ponadto transport odpadów powinien odbywać się zgodnie z wymaganiami określonymi w przepisach wydanych na podstawie ust. 7 , który to zobowiązuje ministra właściwego do spraw środowiska do określenia w drodze roz-

24 B. Rakoczy, Utrzymanie czystości i porządku w gminie $w$ prawie polskim, LexisNexis 2012, s. 138. 
porządzenia oraz $\mathrm{w}$ porozumieniu $\mathrm{z}$ ministrem właściwym do spraw transportu, szczegółowych wymagań dla transportu odpadów, w tym dla środków transportu i sposobu transportowania, jak również oznakowania środków transportu. Upoważnienie do wydania rozporządzenia, w którym określone zostaną szczegółowe wymagania dla transportu odpadów jest rozwiązaniem nowym i jak wskazano w uzasadnieniu projektu ustawy o odpadach ${ }^{25}$, „ma poprawić możliwości kontroli obrotu odpadami w Polsce". W uzasadnieniu wskazano ponadto, iż wprowadzenie tego przepisu do ustawy z dnia 14 grudnia 2012 r. o odpadach wynika z odstąpienia przez ustawodawcę od obowiązku uzyskania zezwolenia na transport odpadów.

Należy zauważyć, że drogowy transport odpadów, jako jedna z form gospodarowania odpadami ${ }^{26}$, stanowi szczególny rodzaj działalności gospodarczej, która bez wątpienia, powinna być prowadzona w sposób, zapewniający zarówno bezpieczeństwo dla zdrowia i życia ludzi, jak i ochronę środowiska. Jak można sądzić, powyższe regulacje będą zatem zmierzały do wskazania wymagań, które zapewnią poszanowanie tych wartości. W stanie prawnym obowiązującym na dzień 9 lipca 2014 r., odpowiednie rozporządzenie nie zostało jeszcze wydane, choć mając na względzie przewidzianą w art. 174 ust. 1 u.o. odpowiedzialność karną za naruszenie wymagań, o których mowa w art. 24 ust. 1 u.o., można przypuszczać, że uzgodnienie i przyjęcie nie budzącej zastrzeżeń treści takiego rozporządzenia, będzie stanowiło przedmiot sporów na styku prowadzących działalność gospodarczą związaną z transportem odpadów i organów administracji publicznej.

Mając na względzie szczególny charakter działalności polegającej na drogowym transporcie odpadów, całkowite odejście

25 http://www.sejm.gov.pl/sejm7.nsf/druk.xsp?nr=456, wejście z dnia 09.07.2014 r.

${ }^{26}$ Zgodnie z art. 3 ust. 1 pkt 2 u.o., gospodarowanie odpadami to zbieranie, transport, przetwarzanie odpadów, łącznie z nadzorem nad tego rodzaju działaniami, jak również późniejsze postępowanie z miejscami unieszkodliwiania odpadów oraz działania wykonywane w charakterze sprzedawcy odpadów lub pośrednika w obrocie odpadami. 
od jej reglamentacji budziłoby istotne wątpliwości. W kontekście wymagań, jakie w tym zakresie sformułował ustawodawca unijny $^{27}$, takie rozwiązanie wydaje się wręcz niemożliwe. Zasadniczo pozytywnie należy jednak ocenić odejście od konieczności uzyskiwania zezwoleń w zakresie transportu odpadów na rzecz uzyskania wpisu do rejestru, który, jak wskazano powyżej, nie stanowi rejestru działalności regulowanej w rozumieniu art. 64 ust. 1 u.s.d.g. Biorąc pod uwagę zakres wniosku o wpis do rejestru, jaki określa art. 53 ust. 5 u.o., a także mając na względzie materialno-techniczny charakter samego wpisu, można stwierdzić, że zmiany, jakie wprowadziła ustawa z dnia 14 grudnia 2012 r. o odpadach, pozwolą „uwolnić przedsiębiorców od obciążeń biurokratycznych"28, jakie związane są z koniecznością przygotowania nierzadko obszernej dokumentacji stanowiącej wniosek o wydanie zezwolenia na prowadzenie tego rodzaju działalności gospodarczej. W przypadku podmiotów, których działalność koncentruje się na przewiezieniu odpadów od ich posiadacza do miejsca przeznaczenia oraz posiadacza odpadów, które zostały im wskazane przez zlecającego usługę, dokonanie wpisu do rejestru, bez uszczerbku dla środowiska należy uznać za wystarczającą formę reglamentacji. Podkreślenia bowiem wymaga, iż pomimo odejścia od obowiązku uzyskania decyzji zezwalającej na transport odpadów, wskazane przez ustawodawcę warunki, których spełnienie ma na celu ochronę zdrowia i życia ludzi oraz środowiska, obowiązują wszystkie podmioty podejmujące tego rodzaju działalność.

27 Zob. art. 26 lit. a dyrektywy Parlamentu Europejskiego i Rady 2008/98/ WE z dnia 19 listopada 2008 r. w sprawie odpadów oraz uchylająca niektóre dyrektywy, Dz.Urz. UE L 312/3, 22.11.2008 - „O ile poniżej wymienione podmioty nie podlegają wymogom uzyskania zezwolenia, państwa członkowskie zapewniają, aby właściwy organ prowadził rejestr [...] przedsiębiorstw zajmujących się zawodowo zbieraniem lub transportem odpadów".

28 T. Szymanek, Swoboda działalności gospodarczej, EWSPIA 2010, s. 184. 


\section{BIBLIOGRAFIA}

Górski M., Zbieranie i transport odpadów, „Przegląd Komunalny” 2008, nr 2.

Jerzmański J., Przemieszczanie odpadów - problemy na styku regulacji, [w:] Wybrane problemy prawa ochrony środowiska, B. Rakoczy, M. Pchałek (red.), Wolters Kluwer 2010.

Karpus K., [w:] Ustawa o odpadach. Komentarz, B. Rakoczy (red.), LexisNexis 2013.

Radecki W., Ustawa o odpadach. Komentarz, Wolters Kluwer 2013.

Radecki W., Ustawa o utrzymaniu czystości i porzadku w gminach. Komentarz, Wolters Kluwer 2012.

Rakoczy B., Utrzymanie czystości i porządku $w$ gminie $w$ prawie polskim, LexisNexis 2012.

Strachowska R., Ustawa o transporcie drogowym. Komentarz, Wolters Kluwer 2012.

Szymanek T., Swoboda działalności gospodarczej, EWSPIA, 2010.

Kontakt e-mail:

anianiec@wp.pl 